\title{
FILSAFAT ILMU-ILMU KEISLAMAN INTEGRALISTIK: STUDI PEMIKIRAN KUNTOWIJOYO
}

\author{
M. Zainal Abidin \\ Fakultas Ushuluddin dan Humaniora \\ IAIN Antasari Banjarmasin
}

\begin{abstract}
This paper departs from the spirit to build the integrative science. Development of integrative science is an important issue for the Islamic world, not just merely as part of an effort to overcome the problem of the dichotomy of science, which is the root of the problem of dropping people and their stuttering in facing the challenges of modernity, but also be an option in solving various problems of contemporary humanity, which can not be solved completely by using Western science.The findings of this paper. First, the construction of the Islamic paradigm in the development of integrative science rests on spirit of Islamic scientification. Secondly, the paradigm of Islam is considered to have strong prospects in developing the Islamic sciences that relevant to the realities and needs of Muslims.
\end{abstract}

Kata kunci: paradigma Islam, ilmu integralistik, pengilmuan Islam

\section{Pendahuluan}

Salah satu persoalan yang cukup mengemuka dalam diskursus pemikiran muslim kontemporer adalah bagaimana merumuskan dan mengembangkan kembali ilmu-ilmu keislaman yang relevan dengan kebutuhan umat Islam dalam menghadapi tantangan dan perubahan zaman yang terus berkembang sangat pesat. Perumusan ini dipandang penting, mengingat "ilmu-ilmu keislaman" yang selama ini diwarisi dari ilmuwan muslim terdahulu seperti ilmu kalam, fikih, falsafah, dan tasawuf seringkali kurang atau tidak memiliki relevansi khusus dalam membantu umat Islam untuk memahami dan sekaligus bekal dalam menghadapi realitas kehidupan mereka sehari-hari.

Ilmu-ilmu keislaman yang pada masa dahulu barangkali memiliki relevansi dengan kebutuhan umat, namun perubahan dan tantangan zaman yang berbeda menjadikan ilmu-ilmu tersebut kehilangan peran sentral. Fazlur Rahman melihat bahwa ilmu-ilmu keislaman yang berkembang saat ini sebagai disiplin ilmu, sangat sedikit menghasilkan pikiran-pikiran ataupun gagasan baru. Isinya lebih banyak berupa pengulangan-pengulangan atau komentar terhadap suatu karya. ${ }^{1}$ Kurang atau tidak adanya relevansi khusus antara ilmu-ilmu keislaman dengan realitas yang berkembang masa kini telah menjadikan umat Islam kehilangan peran sentral dalam merespons tantangan modernitas. Hal inilah yang oleh Shabbir Akhtar disebut sebagai bukti utama dari kelumpuhan intelektual umat Islam. ${ }^{2}$

Berbeda dengan realitas ilmu di dunia Islam yang seolah berjalan di tempat (mandeg/stagnan), ilmu-ilmu modern yang berkembang di Barat tumbuh subur seiring dengan perubahan tantangan kehidupan yang semakin kompleks. Ilmu-ilmu modern seperti sains kealaman, sosiologi, antropologi, psikologi, hermeneutika, dan bidang-bidang ilmu lainnya berkembang dengan pesat di Barat dan

\footnotetext{
${ }^{1}$ Lihat Fazlur Rahman, Islam and Modernity: Transformation of an Intellectual Tradition (Chicago and London: The University of Chicago Press, 1982), h. 37-38.

${ }^{2}$ Lihat Shabbir Akhtar, Islam Agama Semua Zaman (Faith for All Seasons: Islam and Western Modernity), terj. Rusdi Djana (Jakarta: Pustaka Zahra, 2002), h. 7.
} 
terus berproses sebagai bentuk respons ilmuwan Barat terhadap realitas dan kebutuhan terkini masyarakat di sana.

Menyikapi realitas ketertinggalan umat Islam di bidang ilmu ini, sementara pemikir Muslim kemudian menjadikan ilmu-ilmu yang berkembang di Barat tersebut sebagai referensi bagi dunia Islam dalam menghadapi tantangan modernitas. Mereka berpandangan bahwa ilmu itu merupakan alat atau instrumen yang netral dan dapat dipergunakan secara bebas oleh siapa saja. Bagi mereka, persoalan umat Islam di bidang ilmu dapat diatasi dengan transfer ilmu Barat ke dunia Islam. Pandangan ini bisa dilihat pada figur seperti Sayyid Jamaluddin al-Afgani (1838-1897) ${ }^{3}$, Muhammad Abduh (1849-1905) dan Muhammad Rasyid Ridha (1865-1935). ${ }^{4}$

Sampai pada titik ini ada dua model keilmuan yang berkembang di dunia muslim. Pertama, mereka yang bertahan dengan model ilmu-ilmu keislaman klasik, yang meski sarat dengan nilai-nilai keislaman, namun sangat terbatas serta kurang memiliki relevansi khusus dengan kebutuhan umat dalam menghadapi tantangan kehidupan. Model keilmuan ini mendapatkan kritikan keras dari banyak pemikir muslim kontemporer. Kedua, mereka yang mengadopsi ilmu-ilmu Barat, yang dipandang relevan dengan realitas zaman sekarang, namun ternyata berpijak pada nilai-nilai yang berbeda dengan Islam. Kelompok ini juga mendapatkan tantangan tajam dari sebagian pemikir muslim kontemporer lainnya.

Berangkat dari kenyataan ini, maka lahirlah gagasan untuk pembangunan ilmu yang integralistik, sebagai jalan tengah untuk mengambil aspek positif dari kedua model keilmuan di atas. Aspek positif dari ilmu-ilmu keislaman adalah nilai-nilai Islam yang melekat padanya; sedangkan aspek positif pada ilmu-ilmu Barat adalah relevansinya terhadap tantangan zaman. Ilmu integralistik yang dimaksud di sini adalah model keilmuan yang disamping memiliki nilai dan ruh keislaman juga sekaligus relevan dengan kebutuhan umat Islam dalam menghadapi berbagai persoalan kehidupan yang semakin kompleks. Pembangunan ilmu integralistik menjadi isu penting bagi dunia Islam, tidak saja semata sebagai bagian dari upaya untuk mengatasi problema dikotomi ilmu, yang merupakan akar persoalan dari ketertinggalan umat serta kegagapan mereka dalam menghadapi tantangan modernitas, tetapi juga menjadi pilihan dalam mengatasi berbagai persoalan kemanusiaan kontemporer, yang tidak dapat diselesaikan secara tuntas dengan menggunakan ilmu Barat.

Salah satu tokoh yang menggagas ilmu integralistik ini adalah Kuntowijoyo. Bangunan ilmu integralistik Kunto berangkat dari paradigma Islam sebagai pijakan, melalui proses yang disebut pengilmuan Islam. Pengilmuan Islam bertitik tolak dari Islam itu sendiri, yakni al-Qur'an sebagai basis pengembangan teori ilmu. Gagasan ini oleh Kunto dipandang sebagai antitesis dari Islamisasi ilmu, sebuah proyek intelektual dari Barat ke dunia Islam, sedangkan pengilmuan Islam merupakan proyek intelektual dari dalam Islam ke dunia luar.

Ada tiga pokok persoalan dari pemikiran paradigma keilmuan Islam Kuntowijoyo yang dikaji dalam tulisan ini, yaitu: (1) persoalan konstruksi paradigma keilmuan Islam Kuntowijoyo; (2) persoalan landasan filosofi paradigma Islam; dan (3) persoalan prospek paradigma Islam dalam pembangunan ilmu yang integralistik.

${ }^{3}$ Lihat Zainal Abidin Bagir, "Pergolakan Pemikiran di Bidang Ilmu Pengetahuan”, dalam Taufik Abdullah etal. (ed.), Ensiklopedi Tematis Dunia Islam (Jakarta: Ichtiar Baru van Hoeve, 2002), h. 138.

${ }^{4}$ Lihat Emad Eldin Shahin, Through Muslim Eyes: M. Rashid Rida and the West (Virginia USA: IIIT, 1994), h. 44. 


\section{Biografi dan Karya-karya Kuntowijoyo}

Kuntowijoyo atau lebih akrabnya dipanggil Kunto dilahirkan di Bantul, Yogyakarta pada 18 September 1943, sebagai anak kedua dari sembilan bersaudaradari pasangan Sosro Martoyo dan Warasti. Nama Kuntowijoyo sendiri merupakan pemberian kakeknya yang bernama Marto Sumo. Kakeknya ini semasa hidup merupakan lurah Desa Ngawonggo, Ceper, Klaten. Sebagai lurah, ia memiliki prestasi yang bagus, sehingga oleh Kraton diberi gelar Raden Demang Marto Sumo. Gelar ini merupakan penghargaan Kraton yang diberikan kepada lurah yang terbaik.

Melihat latar belakang keluarga, lingkungan, serta kondisi geografis, maka wajar apabila kemudian pengaruh budaya Jawa yang kental dan nilai Islam yang ketat tertanam cukup erat pada diri Kuntowijoyo. Ketika sudah dewasa, sering Kunto disebut rekan-rekannya sebagai sosok yang sangat Islami sekaligus njawani (very Islamic dan very Javanese). ${ }^{5}$

Setamat SMP pada tahun 1959 dan SMA II A Surakarta tahun 1962, Kuntowijoyo kemudian masuk di Jurusan Sejarah, Fakultas Sastra (kini Fakultas Ilmu Budaya) Universitas Gadjah Mada, Yogyakarta. Pilihan untuk masuk di Jurusan Sejarah ini betul-betul didasarkan pada kesadaran Kuntowijoyo. Pada tahun 1969, Kuntowijoyo berhasil meraih gelar sarjana di UGM, dan kemudian diangkat menjadi staf pengajar. Pada tahun 1973, dengan beasiswa dari Fullbright, ia melanjutkan studi ke The University of Connecticut USA hingga meraih gelar MA (Master of Art) dalam American Studies. Pada tahun 1980, Kunto berhasil membawa pulang gelar Ph.D. dari Colombia University program beasiswa dari Rockfeller Foundation dengan menulis disertasi berjudul "Social Change in an Agrarian Society: Madura, 1850-1940."

Sepulang dari AS, Kuntowijoyo mulai semakin terlibat dalam berbagai kegiatan Muhammadiyah bersama rekan sejawat, Amien Rais, Ichlasul Amal, Ahmad Watik Pratiknya, dan lainnya. Namun, Kunto lebih tampil sebagai pemikir, budayawan, dan sastrawan daripada aktivis. Kesantriannya tidak mengurangi daya kritis kesadaran keagamaan yang berkembang di kalangan umat Islam dan komunitas Muhammadiyah.

Pada sekitar tahun 1990-an, bagian otak Kuntowijoyo terserang virus meningo enchepalitis. Sejak itu saraf motoriknya mengalami gangguan serius, mulai mengalami kesulitan untuk menuangkan serta menyampaikan gagasan melalui kata-kata.Hampir dua tahun dia sempat tidak berkarya, namun secara perlahan Kunto terus mencoba menuangkan ide kreatifnya dengan terus menulis. Dengan segala keterbatasan, Kunto berhasil mengetik sendiri naskah pidato pengukuhan sebagai Guru Besar pada Ilmu Sejarah Fakultas Ilmu Budaya Universitas Gadjah Mada (UGM) Yogyakarta, pada tahun 2001. Naskah pidato pengukuhan yang disusunnya berjudul "Sejarah Kesadaran Umat Islam: Mitos, Ideologi, dan Ilmu”. Kuntowijoyo meninggal dunia di Rumah Sakit Dr. Sardjito Yogyakarta, Selasa 22 Februari 2005 pukul 16.00 akibat komplikasi penyakit sesak nafas, diare dan ginjal, dan dikebumikan keesokan harinya di pemakaman keluarga UGM, di Sawitsari, Yogyakarta.

Sebagai seorang intelektual dan akademisi serta juga sekaligus budayawan, Kuntowijoyo menulis pada banyak bidang ilmu. Karya intelektual dan akademisi yang telah dihasilkannya antara lain: Dinamika Sejarah Umat Islam Indonesia (1985); Budaya dan Masyarakat (1987); Paradigma Islam: Interpretasi untuk. Aksi (1991); Demokrasi dan Budaya Birokrasi (1994); Identitas Politik Umat Islam (1997); Pengantar Ilmu Sejarah (2001); Muslim Tanpa Masjid (2001); Selamat Tinggal Mitos, Selamat Datang Realitas (2002); Radikalisasi Petani: Esai-esai Sejarah Kuntowijoyo (2002); Raja, Priayi, dan Kawula: Surakarta 1900-1915

\footnotetext{
${ }^{5}$ Chairil Anwar, “Jika Seorang Seniman Mangkat”, dalam Zen Rachmat Sugito (peny.), Muslim Tanpa Mitos, h. 218.
} 
(2004); dan Islam Sebagai Ilmu: Epistemologi, Metodologi, dan Etika (2004). Sementara, sebagai seorang budayawan, karya-karya Kunto yang telah dipublikasikan antara lain: Kereta Api yang Berangkat Pagi Hari (Novel, 1966); Rumput-rumput Danau Bento (Drama, 1968);Tidak Ada Waktu Bagi Nyonya Fatma, Barda, dan Cartas (Drama, 1968); Pasar (Novel, 1972); Topeng Kayu (1973); Suluk Awang-Uwung (Kumpulan Sajak, 1975); Isyarat (Kumpulan Sajak, 1976); Khotbah di Atas Bukit (Novel, 1976); Dilarang Mencintai Bunga (Kumpulan Cerpen, 1992); Makrifat Daun, Daun Makrifat (Kumpulan Sajak, 1995); Hampir Sebuah Subversi (Kumpulan Cerpen, 1999); Mantra Pejinak Ular (Novel, 2000); Mengusir Matahari: Fabel-fabel Politik (Kumpulan Kolom, 2001); dan Waspirin dan Satinab (Novel, 2003).

\section{Konstruksi Paradigma Keilmuan Islam Kuntowijoyo}

\section{Konstruksi Ontologis}

Sebagaimana disebut pada pengantar di atas bahwa ontologi dalam lingkup kajian filsafat ilmu mencakup hakikat ilmu, sifat dasar, dan kebenaran atau kenyataan yang inheren di dalamnya. Ilmu dalam Islam didefinisikan sebagai pengetahuan sebagaimana apa adanya. ${ }^{6}$ Pengetahuan sebagaimana apa adanya ini diperoleh dari keyakinan terhadap sesuatu yang dijadikan objek penelitian.

Kuntowijoyo lebih memaknai ilmu sebagai suatu kebudayaan. Kebudayaan sendiri bagi Kunto adalah urusan muamalah, sehingga formulasi atau kaidah yang ada pada muamalah juga berlaku padanya, yakni semua boleh kecuali yang dilarang. Meski demikian, menurut Kunto status muamalah ini menjadi hilang tatkala pengetahuan sudah menjadi egoistik, yaitu secara berlebihan merujuk pada dirinya sendiri, yakni menganggap dirinya menjadi penentu segalanya. ${ }^{7}$

Konsekuensi lebih lanjut, pandangan Kunto tentang makna ilmu ini memberikan petunjuk bahwa tuntutan untuk mencari ilmu itu tidak boleh dibatasi dengan rambu halal atau haram. Nabi Muhammad saw. telah memberikan keleluasaan bagi umat Islam untuk mengkaji ilmu, bahkan sampai ke negeri Cina, yang notabene bukankawasan yang "Islami”. Meski demikian, sikap kritis terhadap produk ilmu tetap menjadi tuntutan, karena seringkali suatu bidang ilmu menjadi satu-satunya cara pandang dalam melihat realitas. ${ }^{8}$ Hal ini bagi Kunto merupakan pertanda bahwa ilmu sudah menjadi egois, yang perlu dikritik, dan unsur muamalahnya sudah tidak berlaku lagi.

Terhadap hakikat ilmu, apakah ia pada dirinya memiliki objektifitas ataukah subjektifitas yang kuat sebagaimana perdebatan di kalangan para ilmuwan, Kunto menegaskan bahwa secara prinsip ada rentang antara pengetahuan dengan kesenian. Dengan mengutip pendapat Arthur Koestler dalam "The Act of Creation: A Study of the Conscious and the Unconscious in Science and Art", Kunto menyatakan bahwa ada rentang antara pengetahuan dan kesenian dari yang objective-verifiable sampai ke yang subjective. Rentang itu ialah: Kimia, Biokimia, Biologi, Kedokteran, Psikologi, Antropologi, Sejarah, Biografi, Novel, Epik, dan Lirik. Bagi Kunto, tidak ada kekhawatiran apapun dengan ilmu yang benar-benar objektif dan sejati. Atas dasar ini, maka gagasan Islamisasi ilmu menurut Kunto

${ }^{6}$ Lihat kembali Franz Rosenthal, Knowledge Triumphant: the Concept of Knowledge in Medieval Islam (Leiden: E.J. Brill, 1970), h. 222.

${ }^{7}$ Lihat Kuntowijoyo, Islam Sebagai Ilmu: Epistemologi, Metodologi, \& Etika (Jakarta: Teraju, 2005), h. 9.

${ }^{8}$ Paradigma Cartesian-Newtonian yang menjadi fondasi ilmu modern sering dipandang mengambil sikap seperti ini. Paradigma ini telah mengkonstitusi pandangan dunia modern dan menjadi kesadaran kolektif manusia modern. Padahal, sebagaimana disebut Fritjof Capra, pandangannya yang mekanistik terhadap alam telah melahirkan pencemaran di udara, air, dan tanah yang mengancam balik kehidupan manusia. Lihat Fritjof Capra, The Web of Life (London: Harper Collins, 1996), h. 4-5. Pembahasan lainnya tentang hegemoni paradigma Cartesian-Newtonian ini, lihat Husain Heriyanto, Paradigma Holistik: Dialog Filsafat, Sains, dan Kehidupan Menurut Shadra dan Whitehead (Jakarta: Teraju, 2003), khususnya pada bab II. 
sebagian memang perlu dilakukan, namun sebagian yang lain merupakan pekerjaan yang tidak berguna. ${ }^{9}$

Kuntowijoyo sangat konsern pada arti penting ilmu sebagai suatu cara pandang dalam melihat realitas. Dengan merujuk pada tahapan-tahapan berpikir umat Islam (Indonesia), yakni berpikir mitos, ideologi, dan ilmu, Kunto menempatkan ilmu sebagai tahapan akhir yang harus dikedepankan umat Islam agar mereka bisa memainkan peran dalam kehidupan ini. Tahapan ilmu merupakan tahapan ideal yang memiliki karakter yang sungguh berbeda dengan mitos dan ideologi. Ilmu lebih objektif dalam memandang realitas. Ada perbedaan antara ideologi dan ilmu. Ideologi selalu melihat fakta dari titik subjektif, sedangkan ilmu melihat dari sudut objektif. Selain subjektif, ideologi juga tampak kaku dalam menghadapi kenyataan.

Pada praktiknya, perubahan pola pikir dari mitos, ideologi, dan ilmu tidak harus dipahami secara linear, karena dapat saja tumpang tindih. Sebab, sebagai cara berpikir, mitos dan ideologi bisa muncul kapan saja dan di mana saja, serta bukan milik eksklusif satu kelompok komunitas saja. Manusia dahulu atau sekarang, desa atau kota, dan miskin atau kaya dapat saja pada saat yang sama hidup dalam tiga pola pikir tersebut. Hanya saja bagi Kunto, pilihan untuk mengedepankan tahapan ilmu menjadi suatu keniscayaan bagi umat Islam untuk melangkah lebih maju. Kunto bermaksud membawa umat Islam pada tahapan ini, yakni muslim tanpa mitos. Islam harus dijadikan sebagai ilmu, bukan lagi sebagai ideologi semata, apalagi sebagai mitos.

Bertitik tolak dari gagasan pengilmuwan Islam sebagai sebuah proses, yang kemudian melahirkan paradigma Islam sebagai sebuah produk, satu aspek yang masuk dalam pembahasan seputar konstruksi ontologi dari paradigma keilmuan Islam Kunto adalah pandangannya tentang kebenaran. Kebenaran menurut Kunto sering dicampuradukkan dengan kemajuan, yang berakibat pandangan tentang kebenaran sangat dimungkinkan terpengaruh oleh kemajuan-kemajuan yang disaksikan seseorang. Padahal, menurut Kunto, yang namanya kebenaran itu terpisah dari kemajuan. Kebenaran itu sifatnya tidak bertambah (non-cumulative), sedangkan kemajuan itu bertambah (cumulative). Kebenaran itu tidak makin berkembang dari waktu ke waktu, sedangkan kemajuan itu berkembang. ${ }^{10}$

Kunto menegaskan bahwa sejatinya kebenaran itu apa yang datang dari Tuhan. Dengan bahasa lain, yakni teks wahyu Al-Qur'an yang disampaikan oleh Tuhan kepada baginda Nabi saw. Teori kebenaran menurut Kunto merupakan bagian dari akidah, karena ia termasuk hal-hal yang primer. Peradaban tauhid (theocentric civilization) bersandar pada ketentuan-ketentuan Tuhan untuk yang primer, selebihnya ada kebebasan penuh bagi kreativitas manusia untuk hal-hal yang sifatnya sekunder seperti urusan teknis, strukturasi politik, dan masalah kebudayaan. ${ }^{11}$ Pandangan Kunto tentang peradaban tauhid sebenarnya relevan dengan fakta bahwa semangat ilmiah para ilmuwan dan sarjana muslim pada kenyataannya mengalir dari kesadaran mereka akan tauhid. Menurut Osman Bakar, tidak ada yang lebih baik dalam mengilustrasikan sumber religius semangat ilmiah dalam Islam daripada fakta bahwa semangat ini pertama kali terlihat dalam ilmu-ilmu agama. ${ }^{12}$

${ }^{9}$ Lihat Kuntowijoyo, Islam Sebagai Ilmu, h. 9.

${ }^{10}$ Kebenaran yang dimaksud Kunto di sini, tampaknya merujuk kepada kebenaran yang sudah diterima secara umum. Harus diakui pada bidang agama, filsafat, dan kesenian sebagai disiplin ilmu, perbedaan pandangan sebenarnya lumrah terjadi, demikian pula interpretasi yang sering dikaitkan dengan perkembangan zaman dan perbedaan ruang juga menunjukkan bahwa bidang tersebut sejatinya tidak stagnan, tetapi juga dapat berubah.

${ }^{11}$ Kuntowijoyo, Islam Sebagai Ilmu, h. 5.

${ }^{12}$ Lihat Osman Bakar, Taubid dan Sains: Esai-esai Tentang Sejarah dan Filsafat Sains Islam, terj.Yuliani Liputo (Bandung: Pustaka Hidayah, 1994), h. 13. 


\section{Konstruksi Epistemologis}

Epistemologi sebagai sebuah teori pengetahuan berbicara pada dua persoalan penting dan mendasar, yakni dari mana sumber pengetahuan itu datang dan bagaimana cara untuk mengetahuinya. Kedua persoalan ini saling berkaitan erat ketika dibicarakan. Pembicaraan tentang dari mana sumber pengetahuan diperoleh akan melahirkan uraian tentang bagaimana cara dan strategi untuk menggali sumber ilmu tersebut.

Dengan mendasarkan pandangannya pada Q.S. Fushshilat [41]: 53), Kunto menyatakan bahwa ilmu itu ada pada dasarnya dapat diklasifikasi pada tiga macam, yakni kauniyyah (ilmu-ilmu alam, nomothetic), qauliyyah (ilmu-ilmu Al-Qur'an, theological), dan nafsiyyah (ilmu-ilmu kemanusiaan, hermeneutical. Ilmu kauniyyah berkenaan dengan hukum alam, ilmu qauliyyah berkenaan dengan hukum Tuhan, dan ilmu nafsiyyah berkenaan dengan makna, nilai, dan kesadaran atau dikenal sebagai humaniora. ${ }^{13}$

Pandangan Kunto terhadap adanya tiga macam ilmu ini selaras dengan pemahaman umum dalam wilayah kajian epistemologi Islam bahwa ada tiga tanda-tanda (ayat-ayat) Tuhan yang dapat menjadi sumber ilmu, yakni: ayat-ayat qauliyyah yang potensial melahirkan ilmu-ilmu agama atau teologi; ayat-ayat kauniyyah yang potensial melahirkan berbagai disiplin ilmu kealaman; dan ayat-ayat insaniyyah yang potensial melahirkan ilmu-ilmu dalam bidang sosial-humaniora.

Dengan klasifikasi pada tiga wilayah sumber ilmu di atas, Kunto bermaksud menegaskan bahwa ketiga sumber ilmu tersebut merupakan ayat-ayat Tuhan yang harus dikuasai oleh umat Islam. Dari ketiga wilayah ilmu, Kunto memiliki perhatian khusus pada ayat-ayat qauliyyah yang oleh Kunto dapat dijadikan sebagai sebuah teori besar (grand theory) ilmu. ${ }^{14}$

Dalam konstruksi epistemologi Islam, unsur petunjuk transendental yang berupa wahyu (AlQur'an) menjadi sumber pengetahuan yang tidak kalah penting, bahkan mungkin paling sentral. ${ }^{15}$ Pengetahuan wahyu Al-Qur'an itu menurut Kunto dimasukkan pada pengetahuan apriori yang menempati posisi sebagai salah satu pembentuk mengenai realitas. Sebab, wahyu diakui sebagai ayatayat Tuhan yang memberikan pedoman dalam pikiran dan tindakan. Di dalam konteks ini, wahyu menjadi unsur konstitutif di dalam paradigma Islam. ${ }^{16}$

Konsep-konsep normatif Islam yang berakar pada sistem nilai wahyu dapat diturunkan melalui dua medium, yakni ideologi dan ilmu. Agama menjadi ideologi karena ia tidak hanya mengkonstruksikan realitas, tapi juga memberikan motivasi etis dan teologis untuk merombaknya. Ideologi dengan demikian merupakan derivasi normatif yang diturunkan menjadi aksi. Tapi di pihak lain, agama juga dapat dikembangkan menjadi ilmu dengan merumuskan dan menjabarkan konsepkonsep normatifnya pada tingkat empiris dan objektif. Dengan kata lain, nilai-nilai normatif tidak dijabarkan menjadi ideologi untuk aksi, tapi dirumuskan menjadi teori untuk aplikasi.

Untuk menghindari upaya pereduksian makna sakralitas Al-Qur'an serta tetap mengapresiasi budaya kritik yang merupakan ciri khas ilmu sebagaimana kritikan yang sering ditujukan pada kelompok

${ }^{13}$ Lihat Kuntowijoyo, Islam Sebagai Ilmu, h. 27.

${ }^{14}$ Lihat Kuntowijoyo, Islam Sebagai Ilmu, h. 56.

${ }^{15}$ Dalam Islam sebagaimana dijelaskan al-Attas, epistemologi berkaitan erat dengan struktur metafisika dasar Islam yang telah diformulasikan sejalan dengan wahyu, hadis, akal, pengalaman, dan intuisi. Peradaban Islam itu bermula dari kegiatan tafaqquh terhadap wahyu yang kemudian berkembang tradisi intelektual dan akhirnya menjadi peradaban yang kokoh. Lihat Hamid Fahmy Zarkasyi, "Worldview Sebagai Asas Epistemologi Islam”, dalam ISLAMIA, Tahun II, No. 5/April-Juni 2005, hlm 9-10; lihat juga Mulyadhi Kartanegara, Integrasi Ilmu: Sebuah Rekonstruksi Holistike (Bandung: Mizan, 2005), h. $100-115$.

${ }^{16}$ Lihat Kuntowijoyo, Islam Sebagai Ilmu, h. 18. 
yang memandang Al-Qur'an sebagai sumber ilmu, Kunto memiliki jalan keluar, yakni dengan menjadikan Al-Qur'an sebagai sebuah teori ilmu terlebih dahulu, baru kemudian diaplikasikan. Menurut Kunto, selain dengan mengaplikasikan pesan-pesan wahyu secara langsung, yakni dengan menerapkan aturan Tuhan yang tertera dalam wahyu tersebut secara langsung pada tataran praktis seperti perintah tentang berbakti kepada orang tua dan sebagainya,Al-Qur'an sebagai sumber ilmu juga dilakukan dengan menjadikannya sebagai sumber data perumusan teori ilmu. Pandangan ini terkait dengan pemahaman Kuntowijoyo bahwa Al-Qur'an banyak memuat konsep-konsep yang dapat dianalisis sehingga melahirkan sebuah teori ilmu. ${ }^{17}$

Dengan upaya untuk menjadikan Al-Qur'an sebagai sebuah teori ilmu, ada beberapa keuntungan yang dapat diperoleh. Pertama, ketika teks Al-Qur'an ditempatkan sebuah teori ilmu, maka akan melahirkan desakralisasi terhadap teks, karena bagaimanapun juga yang namanya ilmu senantiasa tidak dapat dilepaskan dari dunia kritik, ia senantiasa harus menerima revisi-revisi kalau memang ditemukan kekurangan atau kelemahan. Inilah karakteristik yang khas dari ilmu. Kedua, dengan menjadi sebuah teori ilmu, tentu saja produk yang akan dilahirkan juga tidak akan berpisah langsung dari induknya, dalam artian nilai-nilai ketuhanan yang melekat pada wahyu secara otomatis juga akan turut serta dalam teori ilmu tersebut. Ini berbeda sebagaimana dinyatakan Kunto dengan ilmu modern yang terpisah dengan nilai-nilai ketuhanan.

Ada jarak sosio-historis antara masyarakat Arab pada waktu Al-Qur'an diturunkan dengan kondisi masyarakat masa kini. Pada masa dahulu Arab adalah masyarakat pra-industrial, masyarakat kesukuan (tribal society), dan masyarakat homogen, sedangkan masyarakat sekarang adalah masyarakat industrial, masyarakat kenegaraan, dan masyarakat heterogen. Kunto meniscayakan penggunaan strukturalisme transendental sebagai metode dan tidak memilih hermeneutika yang umum lazim dipergunakan dalam memahami teks kitab suci, ${ }^{18}$ karena menurutnya yang dibutuhkan umat saat ini bukanlah pemahaman terhadap teks semata, tetapi bagaimana agar dengan teks tersebut dalam dilakukan sebuah proses transformasi umat. ${ }^{19}$

Strukturalisme transendental menurut Kunto akan berguna pada tiga bidang ilmu-ilmu, yakni ilmu-ilmu alam, ilmu-ilmu kemanusiaan, dan agama untuk sekaligus menyadari adanya totalitas Islam dan perubahan-perubahan. Persoalan terbesar bagi Islam menurut Kunto adalah bagaimana mengikuti perubahan dan perkembangan zaman tanpa harus kehilangan jati diri sebagai agama yang kâffah.

Berdasarkan pada pembagian isi Al-Qur'an pada dua kelompok besar, yakni Al-Qur'an yang memuat kisah dan metafora serta konsep-konsep tertentu, maka ada dua pendekatan yang dapat diaplikasikan, yakni: pendekatan sintetik dan pendekatan analitik. Kedua pendekatan ini saling melengkapi satu dengan yang lainnya, dan dipergunakan dengan melihat konteks dari pesan ayat AlQur'an yang dibaca.

Pendekatan sintetik dipergunakan ketika membaca ayat-ayat Al-Qur'an yang memuat kisah dan amtsal. Kuntowijoyo menyatakan bahwa penggambaran-penggambaran arche-type semacam itu

\footnotetext{
${ }^{17}$ Lihat Kuntowijoyo, Paradigma Islam, h. 335.

${ }^{18}$ Istilah hermeneutika berasal dari bahasa Yunani, dari kata kerja "hermeneuen" yang berarti menafsirkan. Adapun kata bendanya "hermenia". Akar kata itu dekat dengan nama salah satu dewa Yunani, yakni dewa Hermes, utusan atau pembawa pesan dari dewa-dewa. Dewa ini mempunyai peranan untuk mengubah apa yang berada di luar pengertian manusia ke bentuk yang bisa dimengerti oleh manusia. Dalam tradisi Islam, Hermes-menurut Sayyed Hossein Nasr - tak lain adalah Nabi Idris, yang dalam filsafat Yunani, dikenal sebagai father of philosopher (Abul Hukama). Lihat J.M. Robinson dan John B. Cobb., The New Hermeneutics (New York: Harper and Row Publisher, 1964), h. 1; lihat Juga Sayyed Hossein Nasr, Knowledge and the Sacred (New York: State University Press, 1989), h. 71.

${ }^{19}$ Kuntowijoyo, Islam Sebagai Ilmu, h. 31.
} 
agar dapat ditarik pelajaran moral dari peristiwa-peristiwa empiris yang terjadi dalam sejarah, bahwa peristiwa-peristiwa itu sesungguhnya bersifat universal dan abadi dalam arti melampaui lokalitas, berupa ruang dan waktu terjadinya peristiwa tersebut. Pendekatan sintetik ini, menurut Kunto, dimaksudkan sebagai upaya merenungi pesan-pesan moral Al-Qur'an dalam rangka mensintesiskan penghayatan dan pengalaman subjektif kita dengan ajaran-ajaran normatif. Melalui pendekatan pemahaman sintetik ini, kita melakukan subjektivikasi terhadap ajaran-ajaran keagamaan dalam rangka mengembangkan perspektif etika dan moral individu. Ini berarti Al-Qur'an difungsikan sebagai media transformasi psikologis dan itu sangat penting dalam rangka penyempurnaan kepribadian Islami. ${ }^{20}$

Apabila pendekatan sintetik sifatnya subjektif, maka pendekatan analitik menghendaki objektivitas dan empirik. Dalam pendekatan analitik, langkah-langkah yang dilakukan adalah, pertamatama Al-Qur'an diposisikan sebagai sumber data, sebagai suatu dokumen mengenai pedoman kehidupan yang berasal dari Tuhan. Ini merupakan suatu postulat teologis dan teoritis sekaligus. Dengan pendekatan ini, ayat-ayat Al-Qur'an menjadi pernyataan-pernyataan normatif yang harus dianalisis untuk diterjemahkan kepada level objektif bukan subjektif. Dengan pendekatan analitik, Al-Qur'an oleh Kuntowijoyo diformulasikan dalam bentuk konstruk-konstruk teoritis. Sebagaimana kegiatan analisis data akan menghasilkan konstruksi teoritis, maka demikian pula analisis terhadap pernyataan-pernyataan Al-Qur'an akan menghasilkan konstruk-konstruk teoritis Al-Qur'an. Elaborasi terhadap konstruk-konstruk teoritis Al-Qur'an inilah yang pada akhirnya merupakan kegiatan Qur'anic theory building, yaitu perumusan teori Al-Qur'an.

\section{Konstruksi Metodologis}

Dalam upaya mengimplemantasikan pengilmuan Islam, Kuntowijoyo menawarkan dua langkah yang harus diambil, yakni: integralisasi dan objektifikasi. Integralisasi adalah pengintegrasian kekayaan keilmuan manusia dengan wahyu (petunjuk Allah dalam Al-Qur'an beserta pelaksanaannya dalam sunnah Nabi). Sementara, objektifikasi adalah menjadikan pengilmuan Islam sebagai rahmat untuk semua orang (rabmatan lil'âlamîn).

Gagasan integralisasi yang ditawarkan Kuntowijoyo berangkat dari pandangan adanya perbedaan yang mendasar antara ilmu-ilmu sekuler yang merupakan produk dari peradaban Barat dengan semangat ilmu-ilmu integralistik yang diidealkan oleh Islam. Perbedaan paradigmatik antara ilmu-ilmu sekuler dengan ilmu-ilmu integralistik tersebut meliputi berbagai aspek yang dapat dirunut mulai dari proses lahirnya sebuah ilmu, yakni pada tempat berangkat, rangkaian proses, produk keilmuan, dan tujuan-tujuan ilmu, yang secara umum meliputi aspek-aspek ontologis, epistemologis, dan aksiologis.

Setelah dilakukan proses integralisasi, maka langkah berikut yang harus dilakukan dalam upaya mengembangkan keilmuan Islam adalah dengan objektifikasi. Kedua aspek ini pada praktiknya harus berjalan secara beriringan. Objektifikasi sendiri menurut Kuntowijoyo bermula dari internalisasi nilai, tidak dari subjektifikasi kondisi objektif. Objektifikasi adalah penerjemahan nilai-nilai internal ke dalam kategori-kategori objektif.

Produk ilmu yang lahir dari induk agama harus menjadi ilmu yang objektif. Artinya, suatu ilmu tidak dirasakan oleh pemeluk agama lain, non-agama, dan anti agama sebagai norma, tetapi sebagai gejala keilmuan yang objektif semata. Meyakini latarbelakang agama yang jadi sumber ilmu atau tidak, tidak menjadi masalah, ilmu yang berlatarbelakang agama adalah ilmu yang objektif, bukan

\footnotetext{
${ }^{20}$ Lihat Kuntowijoyo, Paradigma Islam, h. 329.
} 
agama yang normatif. Maka, objektifikasi ilmu adalah ilmu dari orang yang beriman untuk seluruh manusia, tidak hanya untuk orang yang beriman saja. ${ }^{21}$

Dengan melakukan objektifikasi, menurut Kuntowijoyo, ada dua hal yang bisa dihindari, yakni sekularisasi dan dominasi. Sekularisasi terjadi karena adanya interpretasi yang menganggap bahwa semua peristiwa yang terjadi adalah konsekuensi logis dari gejala objektif. Sementara, dominasi terjadi apabila suatu umat beragama hanya menghasilkan satu produk saja dari internalisasi atas nilai-nilai, yaitu eksternalisasi. Sebab, titik berangkat objektifikasi sama dengan eksternalisasi, yaitu internalisasi. Perbedaannya terdapat pada tujuan, apabila objektifikasi ditujukan keluar, sedangkan eksternalisasi ke dalam umat pemeluk sebuah agama sendiri. Objektifikasi merupakan perbuatan rasional nilai yang diwujudkan ke dalam perbuatan rasional, sehingga orang luar pun dapat menikmati tanpa harus menyetujui nilai-nilai asal.

\section{Konstruksi Etis}

Paradigma Islam yang diperkenalkan oleh Kuntowijoyo berangkat dari sebuah keyakinan bahwa ilmu itu tidak ada yang benar-benar netral. Ilmu pada dasarnya tidak ada yang bebas nilai, ia sarat dengan bias-bias dan kepentingan dari para perumusnya. Ilmu modern yang selama ini sering diklaim bebas nilai, sehingga dapat dimanfaatkan oleh siapa saja, ternyata tidak terlepas dari nilai-nilai yang dianut oleh para perumusnya, yang dalam hal ini adalah nilai-nilai Barat. Argumentasi pandangan ini didukung oleh gagasan paradigma yang disebut oleh Thomas Kuhn, dan kemudian diapresiasi oleh Kuntowijoyo bahwa para ilmuwan itu bekerja dalam sebuah paradigma tertentu.

Keilmuan Islam, yang bekerja dalam bingkai paradigma Islam juga tidak menafikan fakta semacam ini. Menurut Kunto, sebagai ilmu yang bersumber langsung kepada teks wahyu, maka nilai etis yang dikandung oleh keilmuan Islam juga meniscayakan etika yang kental dengan muatan keislaman. Dalam banyak tulisan, Kunto sering mengungkapkan istilah profetik atau kenabian sebagai visi etis dari ilmu sosial yang ditawarkannya. Gagasan etika profetik atau kenabian diasumsikan sebagai suatu bentuk etika yang menjadi misi Muhammad dalam menyampaikan pesan kenabiannya, dan dengannya umat Islam diidealkan untuk dibangun. Sumber etika profetik dalam konteks Islam adalah perilaku Nabi Muhammad saw.

\section{Prospek Paradigma Ilmu Integralistik}

\section{Aspek Koherensi-Konsistensi}

Fokus kajian pada aspek koherensi-konsistensi gagasan paradigma keilmuan Islam Kuntowijoyo adalah: sejauh mana gagasan paradigma keilmuan Islam Kuntowijoyo dapat diterima secara logika penalaran dalam upaya untuk membangun ilmu yang integralistik dan mengatasi problem dikotomi ilmu yang selama ini berlaku di dunia Islam. Fokus ini sangat terkait dengan apa dinamakan relevansi intelektual, yakni apakah gagasan paradigma keilmuan Islam Kuntowijoyo memiliki koherensikonsistensi yang logis dalam membangun ilmu integralistik serta mengatasi problem dikotomi ilmu yang berlaku di dunia muslim.

Dari empat aspek yang merupakan bagian dari bangunan filsafat ilmu secara umum, Kunto lebih banyak berbicara sekitar aspek epistemologis, metodologis, dan aspek etis. Adapun pada aspek ontologis hanya sedikit diuraikan, karena Kunto menganggap bahwa apa yang dipaparkan bukanlah

\footnotetext{
${ }^{21}$ Kuntowijoyo, Paradigma Islam, h. 56.
} 
sesuatu yang baru sama sekali. Ikhtiar membangun ilmu integralistik bukanlah hal yang aneh, khususnya dalam tradisi filsafat Islam.Karena itu, basis ontologis dari paradigma Islam tidak mendapat perhatian yang khusus darinya. Kunto sendiri menyebut bahwa Armahedi Mahzar adalah salah satu di antara yang telah memberikan ulasan pada aspek ontologi dalam satu buku tentang integralisme. ${ }^{22}$

Kunto dengan gagasan paradigma Islam tampak menghendaki adanya cara pandang baru terhadap realitas, yakni dengan menggunakan Al-Qur'an sebagai kacamata atau paradigma. Dalam hal ini Kunto mengandaikan Islam dilihat sebagai strukturalisme transendental, yakni Islam merupakan sebuah bangunan utuh yang saling berhubungan serta bersifat transenden, dalam arti melampaui ruang dan waktu. Kunto menyebut dua pendekatan yang harus dilakukan, yakni pendekatan sintesis dan pendekatan analitis. Pendekatan pertama terkait dengan kisah-kisah atau perumpamaan yang banyak terdapat dalam Al-Qur'an, yakni kemampuan pembaca untuk mensintesiskan pengalaman dia dalam suatu ruang dan waktu kepada berbagai kisah dan metafor dalam Al-Qur'an. Dalam hal ini yang terpenting menurut Kunto bukan alur cerita yang diungkapkan Al-Qur'an, tetapi substansi pesan Al-Qur'an itu jauh lebih penting. Sementara pendekatan kedua terkait dengan konsep-konsep kunci dari ayat-ayat Al-Qur'an, yakni pembaca melakukan eksplorasi terhadap konsep-konsep kunci dari ayat-ayat Al-Qur'an, untuk kemudian dibangun suatu teori ilmu. Teori ilmu inilah yang kemudian digunakan dalam melakukan transformasi umat.

Kunto kemudian berbicara tentang metode dalam ikhtiar 'memasarkan' paradigma Islam. Ada dua model yang ditawarkan, yakni model integralisasi dan objektifikasi. Model pertama terkait dengan penguatan ide utama dia bahwa integralisasi atau lahirnya ilmu-ilmu yang integral merupakan sebuah keniscayaan. Adapun model kedua merupakan suatu strategi yang harus dilakukan agar produk ilmu yang lahir dari rahim Al-Qur'an dapat diterima oleh publik yang plural.

Pada tahapan etis, produk keilmuan yang berbasis paradigma Islam diidealkan dapat menjadi media yang mendekatkan seorang hamba kepada Tuhan, sebagaimana pada ilmuwan dahulu bekerja mengamati alam semesta untuk mencari jejak Tuhan di sana. Paradigma Islam juga dituntut untuk terlibat dalam aktivitas sosial berupa visi umat terbaik yang harus diwujudkan umat Islam, yakni visi transformasi, visi liberasi, dan visi transendensi (Q.S. Ali Imran [3]: 110). Meski paradigma Islam dinyatakan sebagai produk orang beriman bagi umat manusia, namun objektifitas dalam hal metodologis merupakan harga mutlak yang tidak dapat ditawar untuk pengembangan ilmu, dan itu diharapkan menjadi alternatif dalam pengembangan ilmu, khususnya bagi umat Islam.

Dengan mengamati alur pemikiran Kunto, didapati tahapan-tahapan yang mesti dilalui dalam membangun paradigma Islam, yakni tahapan cara pandang (strukturalisme transendental), kemudian model pendekatan atau pembacaan terhadap Al-Qur'an (sintesis dan analisis), selanjutnya metode aplikasi paradigma Islam (integralisasi dan objektifikasi) dan diakhiri pada dimensi etis. Tahapantahapan yang dikemukakan Kunto ini cukup memenuhi logika penalaran, yakni ada cukup kejelasan langkah-langkah yang harus dilalui dalam mewujudkan gagasan paradigma Islam.

Terkait dengan formulasi ilmu integralistik yang ditawarkan Kunto, yang dimulai dari agama, kemudian memunculkan teoantroposentis untuk selanjutnya melahirkan dediferensiasi serta diakhiri dengan pembangunan ilmu integralistik, perlu diberikan catatan tersendiri. Dalam hal ini, titik pijak harus lebih spesifik, yakni filsafat Islam, yang dalam tradisinya senantiasa memadukan antara akal dan wahyu (teoantroposentris), kemudian secara otomatis membentuk dideferensiasi dan melahirkan ilmu

${ }^{22}$ Lihat kembali Kuntowijoyo, Islam Sebagai Ilmu: Epistemologi, Metodologi, \& Etika (Jakarta: Teraju, 2005), h. 62; lihat juga Armahedi Mahzar, Integralisme: Sebuah Rekonstruksi Filsafat Islam (Bandung: Pustaka, 1983). 
yang integralistik. Penempatan filsafat Islam sebagai basis pembangunan ilmu ini didasarkan pada pemahaman yang diyakini secara umum bahwa induk semua ilmu itu ada pada filsafat, dan khazanah keilmuan Islam sudah semestinya menjadikan filsafat Islam sebagai basis kajian ontologisnya.

Dalam filsafat Islam, ada tiga persoalan yang menjadi bahasan utama, yakni persoalan ketuhanan (Ilâhiyyah), persoalan kealaman (kauniyyah), dan persoalan kemanusian (insâniyyah) yang lazim disebut dengan trilogi metafisika. Ketiga persoalan, yakni Tuhan, Alam, dan Manusia akan berbuah kepada keyakinan tentang status ontologis pada masing-masing bagian tersebut yang selanjutnya menjadi objek pengembangan ilmu yang integralistik. Pada saat yang bersamaan, dilihat dari aspek teologis, diskusi sekitar hakikat Tuhan, alam, dan manusia akan menjadi fondasi pada penguatan iman seorang muslim.

Kajian ontologi pada tiga persoalan trilogi metafisika akan berpengaruh pada pembahasan mengenai aspek epistemologis, khususnya yang terkait pada sumber ilmu. Ada tiga sumber yang dituntut kepada umat Islam untuk dieksplorasi secara mendalam, yakni terkait dengan penguakan terhadap tanda-tanda keagungan Tuhan berupa ayat-ayat qauliyyah, ayat-ayat kauniyyah, dan ayat-ayat insâniyyah. Eksplorasi pada ketiga macam ayat tersebut akan menghasilkan beragam varian ilmu, yang semua memiliki makna spiritual yang kuat bahwa itu semua ditujukan untuk memahami tentang keagungan Tuhan. Dilihat dari aspek teologis, ini akan memperkokoh makna Islam sebagai sebuah bentuk kepatuhan dan ketundukkan kepada Allah swt., yang dalam hal ini dimanifestasikan kepada pemahaman terhadap ayat-ayat Tuhan, sehingga dapat menghasilkan kepatuhan (Islam) yang maksimal (kaffah). Adapun pada ranah aksiologis akan menghasilkan suatu pola hubungan yang harmonis dan

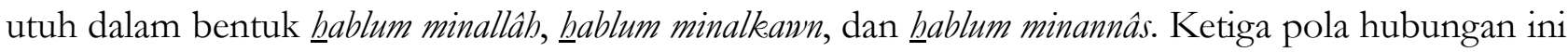
merupakan gambaran relasi yang harus dibangun oleh seorang muslim, dalam posisinya sebagai khalîfatullâh dan pada saat yang bersamaan sebagai 'abdullâh.

Terlepas dari kekurangan Kunto pada aspek filosofi pembangunan ilmu yang integralistik, Kunto telah memberikan sumbangan penting dalam hal cara pandang dan model pembacaan terhadap AlQur'an, yang memungkinkan 'peradaban teks' tidak lagi dilihat sebagai kelompok normatif, yang menerima teks verbal wahyu dalam ketaatan yang mutlak. Selain itu, gagasan objektifikasi Kunto terhadap ilmu-ilmu keislaman akan menjadikan visi Islam sebagai rạmatan li al-'âlamîn semakin kuat dan lebih mungkin untuk diwujudkan.

\section{Aspek Korespondensi}

Sebagaimana disebut pada bagian pendahuluan bahwa problem utama ilmu-ilmu keislaman yang berkembang dewasa ini, yang diwarisi dari masa silam, dipandang tidak terintegrasi dengan kebutuhan dan tantangan zaman yang berkembang pada masa kini. Warisan keilmuan Islam dipandang telah kehilangan kontekstualnya, dan pada saat yang sama, sementara umat Islam kemudian menjadikan ilmu-ilmu Barat yang lebih relevan dengan tuntutan zaman sebagai pilihan.

Persoalan kemudian, ternyata ilmu modern yang dipuja dan diagungkan, belakangan dipandang oleh para intelektual muslim dan kritikus dari ilmuwan Barat sendiri memiliki persoalan-persoalan serius pada dirinya, yang berimbas pada lahirnya corak keilmuan yang alih-alih dapat membuat manusia bahagia, tetapi malah membuat manusia semakin terasing dengan diri dan nilai-nilai kemanusiaan yang melekat dalam dirinya melalui proses yang disebut dengan dehumanisasi.

Dengan melihat realitas ilmu yang semacam ini, maka dibutuhkan alternatif model keilmuan lain yang dapat berkontribusi dalam upaya penyelesaian permasalahan umat manusia. Paradigma keilmuan Islam Kuntowijoyo dapat dilihat dari perspektif ini, meski tujuan utama dari gagasan Kunto 
sendiri lebih diorientasikan kepada pembenahan internal umat Islam. Paradigma Islam dengan seperangkat cara kerjanya oleh Kunto memang diandaikan berfungsi sebagai wahana untuk transformasi umat (Islam). Kunto sendiri secara lugas tidak menggunakan hermeneutika sebagai cara pandang terhadap Al-Qur'an, karena baginya yang penting dan utama bukanlah semata-mata pada pemahaman, akan tetapi bagaimana agar Al-Qur'an itu dapat diterapkan di lapangan.

Bagi Kuntowijoyo, pesan Q.S. Ali Imran [3]: 110 sangatlah kuat, yakni bahwa umat Islam ditegaskan sebagai umat terbaik yang harus terlibat dalam pergumulan kemanusiaan dengan tiga tugas utama, yakni: (1) amr ma'rûfatau dalam istilah kontemporer semakna dengan istilah transfomasi atau perubahan ke arah yang lebih baik; (2) nahî munkaratau dengan bahasa lain liberasi atau pembebasan; dan (3) imân billâh, yakni transendensi berupa hubungan dengan Tuhan.

Humanisasi dilakukan dalam rangka melawan dan melenyapkan keadaan dehumanisasi yang melanda masyarakat modern sebagai dampak negatif kemajuan industri dan teknologi. Manusia mesin yang hanya memiliki satu dimensi, yang hanya dihitung sebagai angka dalam kalkulasi pasar dengan orientasi material, sepantasnya dikritik dengan mengedepankan semangat humanisasi yang berpijak pada ajaran-ajaran Tuhan. Segala tindak-tanduk manusia yang cenderung merendahkan derajat sebagai manusia dalam paradigma Tuhan harus diperbaiki.

Liberalisasi dilakukan untuk mencegah dan melawan berbagai bentuk penindasan, penjajahan, dan penghisapan sekelompok manusia terhadap kelompok manusia lainnya. Dalam hal ini penindasan yang dilakukan pejabat negara, permainan politik yang kotor, penindasan laki-laki atau masyarakat terhadap wanita, dan penindasan etnis atau agama tertentu kepada etnis atau agama lainnya. Tentu saja, pencegahan itu dilakukan menurut hukum-hukum yang disepakati dan tidak menyimpang dari ajaran Tuhan.

Kedua sikap dan tindakan itu kemudian disempurnakan oleh etika transendensi, yaitu mengikatkan kembali keberadaan dan perilaku manusia di bumi (antarmanusia dan antarmakhluk) dengan keberadaan dan kemahakuasaan Tuhan. Di sinilah bersatupadu kesadaran kemanusiaan dengan kesadaran ketuhanan membuat keberadaan manusia menjadi lengkap.

Fungsi amar ma'ruf dalam kehidupan dewasa ini sering dilakukan oleh gerakan kapitalis,nabi munkar oleh kaum sosialis dan transendensi oleh agamawan. Kaum kapitalis (Barat) sebagaimana diketahui sangat bersemangat pada pembangunan dan isu kemanusiaan. Mereka memberikan hibah dana kepada banyak Lembaga Swadaya Masyarakat (LSM) yang melakukan kerja di bidang pemberdayaan dan tranformasi sosial. Kaum sosialis sangat gigih menyuarakan pembebasan terhadap struktur yang tidak adil, pemiskinan yang sistematis, dan pendampingan terhadap kelompok yang tertindas dan termarginalkan. Adapun kaum agamawan sangat sibuk dengan urusan pengabdian kepada Tuhan. Hidupnya diorientasikan untuk bagaimana mengabdi sepenuh hati kepada Tuhan. Urusannya dengan Tuhan adalah di atas segalanya.

Islam sebagai agama pamungkas dan penyempurna memberikan tugas kepada umatnya untuk menyatukan peran kemanusiaan yang diambil secara terpisah oleh kelompok berbeda sehingga dengannya gelar terbaik dapat diperoleh. Fungsi kemanusiaan sebagaimana disebutkan di atas harus dijalankan secara integral dan tidak boleh dipisahkan karena akan berakibat fatal. Proses humanisasi harus dilakukan secara bersamaan dengan proses liberasi, dan pada saat yang sama tidak boleh lepas dari nilai ketuhanan. Ketiganya secara bersamaan akan bersinergi dalam membangun kualitas umat terbaik yang harus diraih umat Islam. 


\section{Peluang Paradigma Integralistik}

Pembahasan tentang peluang paradigma Islam dalam diskursus keilmuan muslim kontemporer meniscayakan pembacaan terhadap pemikiran sejenis dari "kompetitor" pemikiran keilmuan Islam integralistik. Pembacaan ini bertujuan untuk mengetahui kemungkinan penerimaan dari kalangan intelektual muslim terhadap paradigma Islam sebagai sebuah gagasan yang berguna dalam pembangunan ilmu integralistik di dunia muslim.

Kelompok dari pemikir muslim kontemporer yang memiliki konsern kuat pada upaya mewujudkan ilmu-ilmu keislaman yang genuine (orisinil) vis-à-vis berhadapan dengan ilmu modern Barat adalah dari kelompok yang disebut Islamisasi ilmu. Sejatinya ada banyak varian pada kelompok ini, namun secara umum ada dua arus utama yang terkadang memiliki dasar pandangan yang bertolakbelakang apabila dilihat dari konteks tradisi dan modernitas, meski semangat yang diusung serupa, yaitu pada perlunya Islamisasi ilmu. Kedua pandangan tersebut diwakili oleh dua pemikir besar Islamisasi ilmu, yaitu Syed M. Naquib al-Attas dan Ismail Raji al-Faruqi.

Dilihat dari perspektif Islamisasi ilmu, pandangan paradigma Islam Kunto tampaknya lebih dekat kepada pemikiran al-Attas. Pandangan al-Faruqi yang lebih menitikberatkan pada aspek modernitas (Barat) sebagai pijakan awal, oleh Kunto dipandang sebagai 'lawan' dari gagasan paradigma Islam. Apabila Islamisasi ilmu model Faruqian yang berupaya membawa ilmu-ilmu Barat kepada Islam, maka semangat paradigma Islam adalah sebaliknya, yaitu bagaimana menjadikan Islam (baca: wahyu) sebagai dasar pijakan dari pengembangan ilmu atau dalam bahasa Kunto bagaimana menjadikan Islam sebagai ilmu melalui proses yang disebutnya pengilmuwan Islam.

Selanjutnya, apabila dilihat secara utuh, mulai konstruksi ontologis, konstruksi epistemologis, konstruksi metodologis, dan konstruksi etis, terlihat bahwa bangunan paradigma Islam Kuntowijoyo masih belum begitu terhubung secara kokoh. Kekaburan pembahasan pada aspek ontologis ini misalnya berpengaruh pada gagasan paradigma Islam yang belum tergambar dengan jelas dari mana titik tolak yang harus ditempuh dalam upaya merumuskan ilmu yang integralistik, yang dapat mengatasi problem dikotomi ilmu. Namun, ketidakjelasan paparan Kunto tersebut dapat diatasi dan dilengkapi dengan menggunakan pembacaan yang telah dilakukan oleh intelektual muslim lain, yang juga memiliki perhatian sama pada upaya pembangunan ilmu yang integralistik, seperti Syed Naquib al-Attas dan Alparslan Acykgenc.

Bagi al-Attas, yang namanya Islamisasi ilmu harus dimulai dari adanya penanaman terhadap pandangan dunia Islam (Islamic worldview) dalam kehidupan individu seorang muslim, baru kemudian proses Islamisasi ilmu pun berlaku secara serentak. Selanjutnya al-Attas juga menegaskan bahwa dalam Islam, wahyu merupakan sumber utama dalam tentang realitas dan kebenaran akhir berkenaan dengan makhluk ciptaan dan pencipta. Wahyu merupakan dasar dalam mengelaborasi filsafat sains sebagai sebuah sistem yang menggambarkan realitas dan kebenaran. Tanpa wahyu, ilmu hanya akan menyentuh aspek yang fenomena. Akibatnya, kesimpulan kepada fenomena akan selalu berubah sesuai dengan perkembangan zaman. Tanpa wahyu, realitas yang dipahami hanya terbatas kepada alam nyata ini yang kemudian dianggap sebagai satu-satunya realitas. Inilah salah satu yang khas dalam upaya pengembangan keilmuan di dunia Islam. ${ }^{23}$

Paparan al-Attas ini kemudian dipertegas oleh Alparslan yang menyebutkan bahwa dalam tahapan-tahapan proses berkembangnya ilmu-ilmu dalam Islam, Islamic worldview yang berpijak pada

${ }^{23} \mathrm{Al}$-Attas, Islam and Secularism, h. 42. 
wahyu merupakan basis awal, yang kemudian berlanjut pada tahapan-tahapan selanjutnya. Di sini, ada tiga tahapan yang dikemukakan Alparslan: (1) wordview dari para ilmuwan yang merupakan lingkungan konseptual di mana aktivitas keilmuan dikembangkan; (2) jaringan konseptual ilmu yang telah jelas bentuknya yang disebut dengan struktur konsep keilmuan; dan (3) jaringan teknis dan cara pandang yang dihasilkan jaringan konsep dalam suatu ilmu tertentu yang disebut juga sebagai struktur keilmuan khusus. ${ }^{24}$ Tahapan-tahapan ini pada gilirannya hal ini akan melahirkan tradisi keilmuan dalam Islam, yang telah menandai era gemilang peradaban Islam.

Dengan membandingkan paparan al-Attas dan Alparslan di atas dengan gagasan paradigma Islamnya Kuntowijoyo, pandangan-pandangan ini akan saling melengkapi. Kunto memang ada menyebutkan tentang Qur'anic worldview, yakni pandangan hidup yang berpijak pada Al-Qur'an. Bahkan, inilah yang menjadi gagasan utama Kunto bahwa realitas dibaca dan dikonstruksi sebagaimana AlQur'an itu sendiri melihat realitas. Hanya saja, karena latar belakang Kunto yang kurang bersentuhan dengan tradisi klasik Islam serta keterbatasan akses terhadap khazanah filsafat Islam, maka penjelasan dia tentang Quranic worldview belum sampai pada tujuan akhir untuk membangun suatu tradisi keilmuan Islam yang khas, sebagaimana pada masa-masa kejayaan Islam dahulu, tetapi setidaknya itu dapat menjadi embrio ke arah tersebut.

Catatan lain yang dapat diberikan terhadap pemikiran Kunto, bahwa kecenderungan normatif dalam pemikiran paradigma Islamnya sangat kuat. Hal ini terjadi karena memang Kunto bermaksud menjadikan Al-Qur'an sebagai basis perumusan keilmuan integralistik. Pemikiran Kunto ini berbeda misalnya dengan gagasan dari Syed Farid Alatas yang menawarkan diskursus alternatif dalam ilmu sosial Asia sebagai kritikan terhadap hegemoni dan dominasi ilmu sosial Barat. Basis pemikiran Alatas dalam hal ini banyak berpijak pada persoalan empirik, dan bukan semata-mata berbasiskan teologis. ${ }^{25}$

\section{Penutup}

Setelah dilakukan penelitian, dapat dikemukakan hasil bahwa: Pertama, konstruksi paradigma Islam Kuntowijoyo dalam pembangunan ilmu yang integralistik berpijak pada semangat pengilmuan Islam. Ilmu menjadi pilihan dalam menyelesaikan berbagai persoalan umat. Perspektif ilmu juga dipergunakan dalam menggali sumber ilmu. Dari tiga sumber ilmu; ayat-ayat qauliyyah, ayat-ayat kauniyyah, dan ayat-ayat insâniyyah, Kunto menetapkan Alquran (ayat-ayat qauliyyah) sebagai basis paradigma Islam. Untuk kepentingan ini, Alquran didekati dengan dua pendekatan. Pendekatan sintesis untuk pesan-pesan Alquran yang berkaitan dengan kisah atau amtsal. Pendekatan analitis berkaitan dengan konsep-konsep kunci Alquran. Dari segi metodologis, paradigma Islam menawarkan konsep integralisasi dan objektifikasi. Integralisasi, yaitu pemaduan antara ilmu-ilmu wahyu dan temuantemuan manusia. Objektifikasi, yaitu produk ilmu harus benar-benar bersifat objektif. Dilihat dari segi tujuan, paradigma Islam bermaksud melakukan transformasi transendental, yang dalam level implementasi berupaya mengeksplorasi pesan-pesan Alquran dengan visi humanisasi (amr ma'rûf), liberasi (nahî munkar), dan transendensi (îmân billâh).

Kedua, landasan filosofi paradigma Islam terbangun dari nilai-nilai keislaman, keindonesiaan, dan kemodernan. Nilai-nilai tersebut secara bertautan mewarnai pemikiran paradigma Islam Kuntowijoyo. Dengan semangat dari nilai-nilai tersebut, Kunto meyakini bahwa wahyu Alquran

\footnotetext{
${ }^{24}$ Lihat Alparslan Acykgence, "Lahirnya Tradisi Keilmuan dalam Islam”, dalam Majalah Pemikiran dan Peradaban Islam ISLAMIA, Volume III, No. 4, Tahun 2008, h. 36.

${ }^{25}$ Syed Farid Alatas, Diskursus Alternatif dalam Ilmu Sosial Asia, terj. Ali Noer Zaman, (Bandung: Mizan, 2010).
} 
memiliki signifikansi dalam membangun ilmu integralistik dan menghilangkan pandangan dikotomis dalam bidang ilmu. Namun, paparan Kunto yang lebih memperhatikan pada aspek epistemologis dan aksiologis, harus dilengkapi pada sisi ontologis, yakni dengan mendasarkan pijakan pada kajian filsafat Islam, agar konstruksi filsafat keilmuan paradigma Islam akan lebih kokoh dan komprehensif. Selain itu, paradigma Islam Kunto yang cenderung normatif, perlu mengapresiasi hal-hal empirik agar paradigma Islam semakin memiliki signifikansi dalam upaya pembangunan ilmu yang integralistik.

Ketiga, paradigma Islam dinilai memiliki prospek yang cukup kuat dalam melahirkan ilmuilmu keislaman yang relevan dengan realitas dan kebutuhan umat Islam. Namun, prospek ini akan semakin optimal apabila terus dibangun kolaborasi yang integral antara tiga macam ayat-ayat Tuhan, yakni ayat-ayat qauliyyah, ayat-ayat kauniyyah, dan ayat-ayat insâniyyah dengan tetap mengapresiasi kekhasan segenap perangkat dan metode kerja yang umumnya berlaku pada masing-masing ayat-ayat tadi. Paradigma keilmuan Islam yang ditawarkan Kuntowijoyo dilihat dari peta pemikiran keilmuan Islam kontemporer; afirmatif-apologetik, instrumentalis, dan Islamisasi ilmu, merupakan model varian lain, yakni tetap menjadikan Alquran sebagai rujukan, namun dengan model pendekatan dan langkah yang berbeda, karena selain menghadapkan Alquran langsung pada level praksis pengalaman umat manusia pada ruang dan waktu yang berbeda, juga menempatkan Alquran sebagai basis pengembangan teori ilmu. Dengan demikian, konsepsi paradigma keilmuan Islam Kunto akan memperlebar peta pemikiran intelektual muslim dalam upaya pengembangan ilmu di dunia Islam, sekaligus merupakan bantahan terhadap kritikan yang menolak penggunaan Alquran di luar kajian ilmu-ilmu agama.

\section{DAFTAR PUSTAKA}

Abdullah, M. Amin, (2006). Islamic Studies di Perguruan Tinggi: Pendekatan Integratif-Interkonektif, Yogyakarta: Pustaka Pelajar.

Acykgence, Alparslan, (2008). "Lahirnya Tradisi Keilmuan dalam Islam”, dalam Majalah Pemikiran dan Peradaban Islam ISLAMLA, Volume III, No. 4.

Akhtar, Shabbir, (2002). Islam Agama Semua Zaman (Faith for All Seasons: Islam and Western Modernity), terj. Rusdi Djana, Jakarta: Pustaka Zahra.

Alatas, Syed Farid, (2010). Diskursus Alternatif dalam Ilmu Sosial Asia, terj. Ali Noer Zaman, Bandung: Mizan.

Bagir, Zainal Abidin, (2002). "Pergolakan Pemikiran di Bidang Ilmu Pengetahuan", dalam Taufik Abdullah et al. (ed.), Ensiklopedi Tematis Dunia Islam, Jakarta: Ichtiar Baru van Hoeve.

Bakar, Osman, (1994). Taubid dan Sains: Esai-esai Tentang Sejarah dan Filsafat Sains Islam, terj.Yuliani Liputo, Bandung: Pustaka Hidayah.

Capra, Fritjof, (1996). The Web of Life, London: Harper Collins.

Daud, Wan Mohd Nor Wan, (2003). Filsafat dan Praktik Pendidikan Islam Syed M. Naquib Al Attas, Bandung: Mizan.

Heriyanto, Husain, (2003). Paradigma Holistik: Dialog Filsafat, Sains, dan Kehidupan Menurut Shadra dan Whitehead, Jakarta: Teraju. 
J Robinson, M. dan John B. Cobb., (1964). The New Hermeneutics, New York: Harper and Row Publisher.

Kartanegara, Mulyadhi, (2005). Integrasi Ilmu: Sebuah Rekonstruksi Holistik, Bandung: Mizan.

Kuntowijoyo, (2005). Islam Sebagai Ilmu: Epistemologi, Metodologi, \& Etika, Jakarta: Teraju.

Mahzar, Armahedi, (1983). Integralisme: Sebuah Rekonstruksi Filsafat Islam, Bandung: Pustaka.

Mastuhu, (1999). Memberdayakan Sistem Pendidikan Islam, Jakarta: Logos.

Nasr, Sayyed Hossein, (1989). Knowledge and the Sacred, New York: State University Press.

Rahman, Fazlur, (1982). Islam and Modernity: Transformation of an Intellectual Tradition, Chicago and London: The University of Chicago Press.

Rosenthal, Franz, (1970). Knowledge Triumphant: the Concept of Knowledge in Medieval Islam, Leiden: E.J. Brill, 1970.

Shahin, Emad Eldin, (1994). Through Muslim Eyes: M. Rashid Rida and the West, Virginia USA: IIIT.

Wahyudi, Jarot dkk. (ed.), (2003). Menyatukan Kembali Ilmu-ilmu Agama dan Umum (Upaya Mempersatukan Epistemologi Islam dan Umum), Yogyakarta: Sunan Kalijaga Press.

Zarkasyi, Hamid Fahmy, (2005). "Worldview Sebagai Asas Epistemologi Islam", dalam ISLAMLA, Tahun II, No. 5/April-Juni. 